Article

\title{
The Impact of Policy Instruments on Soil Multifunctionality in the European Union
}

\author{
Dirk Vrebos ${ }^{1, *}$, Francesca Bampa ${ }^{2}$, Rachel E. Creamer ${ }^{3}$, Ciro Gardi ${ }^{4}$, Bhim Bahadur Ghaley ${ }^{5}$, \\ Arwyn Jones ${ }^{6}$, Michiel Rutgers ${ }^{7}$, Taru Sandén ${ }^{8}$, Jan Staes ${ }^{1}$ and Patrick Meire ${ }^{1}$ \\ 1 Ecosystem management research group, Department of Biology, University of Antwerp, \\ Universiteitsplein 1c, B2610 Antwerpen, Belgium; jan.staes@uantwerpen.be (J.S.); \\ patrick.meire@uantwerpen.be (P.M.) \\ 2 Crops, Environment and Land Use Programme, Teagasc, Wexford, Ireland; francesca.bampa@teagasc.ie \\ 3 Soil Biology and Biological Soil Quality, Wageningen University and Research, 6700 AA Wageningen, \\ The Netherlands; rachel.creamer@wur.nl \\ 4 Animal and Plant Health (Alpha), European Food Safety Authority (EFSA), Via Carlo Magno 1A, \\ 43126 Parma, Italy; ciro.gardi@efsa.europa.eu \\ 5 Department of Plant and Environmental Sciences, Faculty of Science, University of Copenhagen, \\ Højbakkegård Alle 30, 2630 Taastrup, Denmark; bbg@plen.ku.dk \\ 6 European Commission, Joint Research Centre, Sustainable Resources Directorate, Land Resources Unit, \\ Via E. Fermi 2749, 21027 Ispra, Italy; arwyn.jones@ec.europa.eu \\ 7 National Institute for Public Health and the Environment, Antonie van Leeuwenhoeklaan 9, \\ 3721MA Bilthoven, The Netherlands; michiel.rutgers@rivm.nl \\ 8 Austrian Agency for Health and Food Safety-AGES, Department for Soil Health and Plant Nutrition, \\ Spargelfeldstraße 19, A-1220 Wien, Austria; taru.sanden@ages.at \\ * Correspondence: dirk.vrebos@uantwerpen.be; Tel.: +32-3-265-87-19
}

Academic Editor: Vincenzo Torretta

Received: 26 January 2017; Accepted: 2 March 2017; Published: 9 March 2017

\begin{abstract}
Agricultural ecosystems provide a range of benefits that are vital to human well-being. These benefits are dependent on several soil functions that are affected in different ways by legislation from the European Union, national, and regional levels. We evaluated current European Union soil-related legislation and examples of regional legislation with regard to direct and indirect impacts on five soil functions: the production of food, fiber, and fuel; water purification and regulation; carbon sequestration and climate regulation; habitat for biodiversity provisioning; and the recycling of nutrients / agro-chemicals. Our results illustrate the diversity of existing policies and the complex interactions present between different spatial and temporal scales. The impact of most policies, positive or negative, on a soil function is usually not established, but depends on how the policy is implemented by local authorities and the farmers. This makes it difficult to estimate the overall state and trends of the different soil functions in agricultural ecosystems. To implement functional management and sustainable use of the different soil functions in agricultural ecosystems, more knowledge is needed on the policy interactions as well as on the impact of management options on the different soil functions.
\end{abstract}

Keywords: soil function; European legislation; regional legislation; multifunctionality; soil policy

\section{Introduction}

Agricultural ecosystems provide a range of benefits that are vital to human well-being [1]. These benefits encompass provisioning ecosystem services, such as food, wood, fibers, fuel, and drinking water, but also regulating and cultural services such as carbon storage and aesthetics [2,3]. In turn, a range of ecosystem services and functions affect agricultural productivity [4]. This is 
an important consideration as population growth and changing food consumption patterns mean that agricultural production will need to increase significantly by 2050 compared to $2005[5,6]$. The agricultural community is inclined to focus on the increase of productivity through further intensification. This may, however, lead to trade-offs, such as an overall degradation of soil and their processes and functions within agricultural systems [7], which threaten the long-term provisioning of both agricultural production as well as the delivery of other ecosystem services [8]. Since soil formation and recovery take place over long time periods, the sustainable use of our soils is of high importance.

Ecosystem functioning and the delivery of ecosystem services in agricultural landscapes depend on various soil functions [9]. These soil functions can be defined on a gradient from general to specific capabilities of the soil to support various agricultural, environmental, landscape, and urban applications, such as water regulation, nutrient cycling, soil structure formation, and biological activity [10-12].

Soils and their functions depend on complex interactions between soil components, properties, processes, management, and use. A soil component is defined by Dominati et al. [13] as a biogeochemical species (e.g., nitrate $\mathrm{NO}_{3}{ }^{-}$) or an aggregation of biogeochemical species (e.g., clays) that make up soils. Soil properties are considered to be the physical (e.g., porosity, texture), chemical (e.g., $\mathrm{pH}$, readily available phosphate), and biological (e.g., microbial biomass) characteristics of a soil. These components and properties influence and are influenced by different soil processes [12] that reflect both natural (climate, terrain, hydrological, biological) as well as anthropogenic external drivers (soil use and management). Together, these components, properties, and processes shape the soil functions. Soil functions are manifold, may be grouped according to the principal purposes and ecosystem functioning, and are performed on different levels and scales [14]. Intrinsically, different soil functions can be performed by all soils; however, some soils are more effective at some functions than others due to their components, properties, and so on. [15]. Understandably, a soil cannot provide the maximum of its potential for each function at the same time. Anthropogenic drivers such as land use and management are often used to enhance specific functions within one location, very often at the (unintended) expense of the other functions.

Due to natural as well as anthropogenic drivers, soils can degrade over time chemically (e.g., salinization), physically (e.g., erosion), and biologically (e.g., diversity loss), altering soil properties and processes, reducing essential soil functions, and threatening long-term food security $[9,16]$, as well as the provisioning of many other ecosystem services provided by agricultural soils. This degradation can develop over short and longer time periods. Long-term assurance of both productivity enhancement and other soil functions, while reducing environmental impacts and increasing its resilience, should constitute the entry point for all sustainable agricultural development [17].

Our dependence on soils and their functions for the provisioning of natural resources has long been overlooked by society [8]. Only over the past decades has environmental awareness increased and topics such as soil conservation have become a part of the policy agenda. Through the International Year of Soils initiative in 2015, the United Nations (UN) General Assembly recognized the importance of soils as the foundation for agricultural development, essential ecosystem functions, and food [18]. In parallel, soils play a role in nine out of 17 UN Sustainable Development Goals [19]. The FAO member countries unanimously endorsed a new World Soil Charter during the 39th FAO Conference and the International Technical Panel on Soil produced the first report on the Status of the World Soil Resources [20]. Nevertheless, soil in environmental policies and management systems is often not explicitly included.

This perception of a lower relevance of soil functions and degradation also continues in existing legislation and regulation. For example, in 2002 the European Commission presented an approach to soil protection in a Communication titled "Towards a Thematic Strategy on Soil Protection" [21,22]. This resulted in 2006 in the release of a strategy that included a legislative proposal known as the Soil Framework Directive [23], acknowledging soil as a non-renewable resource in its own 
right. Despite the European Union (EU) Parliament, most EU Member States, and the scientific community acknowledging the need for such a directive $[23,24]$, the proposal was never adopted due to a blocking minority of member states and it was officially withdrawn in 2014 [24-26]. As a result, there is currently no legislation at the EU level that focuses exclusively on soil. However, several other European Regulations and Directives do impact important soil functions in agricultural ecosystems [24]. Member states are responsible for the implementation of EU legislation in their own legislative frameworks. During this implementation, due to the principle of subsidiarity, member states generally have a certain flexibility to adapt the legislation to the national, regional and/or local situations. Therefore, national implementation of EU legislative work can differ widely. For example, the application of the European Rural Development Regulation Framework in The Netherlands and France resulted in two systems; one directed towards nature conservation and one towards a predominantly farmer-orientated implementation, respectively [27]. As a result, uniform European legislation, such Regulations and Directives, can impact soil functions in the member states quite differently. Despite the integration of soils in some European legislation [24], the main absence of suitable legislation results in a continuous degradation of many soils within Europe [28,29].

At the same time, national and regional regulatory frameworks can affect soil functions at a lower level within agro-ecosystems. Some European countries do have in place specific soil legislation that protects soils from one or more pressures [30]. Moreover, while some countries have an overarching primary legislation in place for soil protection such as the Italian [31] and German Federal Soil act [32], others have legislation focused on specific threats [33]. Although most of these laws focus, in the first instance, on different soil degradation processes and related drivers, usually considered as threats to soil processes, they conceivably affect different soil functions to various extents. Finally, many countries do not have any specific strategy that is focused on soil or soil threats, but do have policies that indirectly affect soils and their functions.

In the absence of an overarching directive on soil protection, the aim of this review was to evaluate current soil-related legislation in the EU and member states with regard to direct and indirect impacts on soil functions. The objectives were to (1) compare different examples of national and regional legislation across Europe; (2) develop a policy-related narrative on the (un)intended impact of European legislation, including the importance of the interaction between the EU and lower policy levels, on the different soil functions.

\section{Materials and Methods}

\subsection{Soil Functions}

Different EU, national, and regional legislations from across Europe were analyzed for its impacts on five different soil functions within agricultural land. These functions were derived from the soil-based ecosystems services summarized by Haygarth and Ritz [34] and rearranged to agricultural land use by Schulte et al. [35] and Bouma et al. [36]. The same functions are also used within the "functional land management" framework developed by Schulte et al. [37] and Coyle et al. [38]. These are:

(1) Production of food, fiber and (bio)fuel: traditionally the soil function that provides a livelihood to farmers and associated sectors in the rural environment;

(2) Water purification and regulation: the ability of soils to purify and regulate water for human consumption and maintenance of ecosystem integrity;

(3) Carbon sequestration and climate regulation: the ability of soils to store organic carbon for (a) partial offsetting of GHG emissions and (b) regulation of biological and physical soil processes;

(4) Habitat for biodiversity: both belowground and aboveground diversity;

(5) Recycling of (external) nutrients/agro-chemicals; specifically, the ability of soils to provide a sustainable receptor for external nutrients such as those derived from landless farming systems (e.g., pig and poultry farms), as well as sewage sludge and other organic waste products [15]. 
These integrated functions represent all the soil functions in the proposal of the Soil Framework Directive based on their relevance to agricultural ecosystems. The five functions were specifically fashioned and expressed to facilitate the transfer of complex soil quality information to stakeholders involved in agricultural managed soils.

\subsection{Selection of European Policies}

In recent years, several overviews have been published on EU policy and their effects on different soil threats and functions (e.g., [24,25]). The lists of legal acts presented in these articles were taken as a starting point for the current analysis. The combined list was updated and expanded with other relevant literature such as non-binding communications and European Commission programs by consulting the repository of the European commission (http:/ / eur-lex.europa.eu). For the different policy domains (agriculture, industry, urbanization, climate change, and nature conservation) recent directives and regulations, communications and decisions were added to the existing list. To make sure no documents were missed documents were searched from 2010 onwards.

Depending on the type of legal act, their impact on lower level legislation can differ strongly. For example, some are binding, others are not; some apply to all EU countries, others to just a few. Definitions are summarized as follows:

- Regulations: a binding legislative act. It must be applied in its entirety across the EU.

- Directives: a legislative act that sets out a goal that all EU countries must achieve. However, it is up to the individual member states to devise their own laws on how to reach these goals.

- Decisions: binding on those to whom it is addressed (e.g., an EU country or an individual company) and is directly applicable.

- Recommendations: not binding.

- Communication: a policy document with no mandatory authority.

- Opinions: an instrument that allows the institutions to make a statement in a non-binding fashion, in other words without imposing any legal obligation on those to whom it is addressed.

Although some types are non-binding towards MS, they do have an impact on how legislation across the EU is developed. Therefore, in this review, recent legislative documents were integrated within the analysis and this expanded the list compared to previous reviews. Documents were evaluated covering different policy domains (such as agriculture, industry, and environment).

\subsection{Selection of National and Regional Policy}

At the EU scale, there is a seemingly indeterminate range of different national and regional policy documents, management schemes, projects, and programs that impact soil functions in agro-ecosystems and forestry, directly and indirectly. For example, Kutter et al. [39] identified 410 different measures related to soil conservation within the EU. Therefore, a selection of countries and regions was made, based on expert knowledge with the different authors, as case study examples. The following countries and regions were considered (Belgium-Flanders, The Netherlands, Italy-Emilia-Romagna, and Austria-Upper Austria). Each co-author or group of co-authors selected one or several examples based on their knowledge of available, relevant soil policies within their region. The range of documents was analyzed for their relationship towards EU legislation and their impact on soil properties and functions. Based on this analysis a further selection was made to create the narrative that illustrates the effects that different regional legislations can have on the five soil functions and how they can interact with different EU policies.

\subsection{Document Analysis}

For each of the legal documents selected for the analysis, the original published text was assessed regarding its impact on the selected soil functions. When available, official guiding documents from 
the European Commission or regional governments were used as further clarification of the legal texts. The documents were analyzed through interpretation of the different texts. No analysis software programs were used for the documents.

To make the different impact pathways of legislation on soil functions visible, a differentiation was made in the analysis of the legal acts between direct and indirect effects. Many of the legal acts address soil management and soil properties that, in some way, impact different soil functions. Although the integration of soil functions as a concept in legislation is relatively new, different legal acts do already address some functions directly. The word "function" itself is hardly ever used within the documents; however, often the legal texts do target the different functions, as given in Section 2.1, and describe them as a policy goal within the text. In these cases a direct impact on the soil function was considered.

However, most of the functions are impacted indirectly, sometimes intentionally, but often also unintentionally. Indirect effects are anticipated when the texts do effect a function, part of the function or related processes, but the document does not give the function as a specific target or goal of the text. All soil functions are closely related to each other as they generally depend on partly shared soil properties. Therefore, only the most significant indirect effects of the policy were considered. Effects were only considered within agro-ecosystems and forestry and only then in the top- and subsoil. For example, the effect on deeper geological layers, such as the effect of $\mathrm{CO}_{2}$ storage in deep geological layers [40] to mitigate climate change, was disregarded.

Results for the EC documents were aggregated in one table presenting the different direct and indirect influences. For each of the regional examples a cascade scheme was created illustrating the processes that take place from the policy document to the impact on soil functions.

\section{Results}

\subsection{European Legislation}

Based on an extensive review of EU policy documents, a selection was made of all relevant legislation and policies in the target MS. In total, 35 different documents were considered important for their potential impact on soil functions in agricultural areas: 22 Directives, eight Regulations, four Communications and a single Decision. The direct and indirect impact of these documents on the five different soil functions was then evaluated according to the methodology described in Section 2.4. An overview of the results of the different documents and their impacts is presented in Table 1.

Most policy documents have a direct impact on at least one soil function, but hardly ever a direct impact on all functions. Only the "LIFE Environment subprogram" and the "Resource efficiency roadmap" have a direct impact on all functions. However, generally there is no clear relationship between a specific policy domain and the functions directly affected. For example, agricultural policies do not only address primary production directly, but also the other four functions.

Documents from different policy domains can cover different soil functions and one function can be impacted by documents from different policy domains. Of the different functions, the function "production of food, fiber, and (bio)fuel" is mostly directly affected by the different policies. All the other functions are directly affected by at least some of the policies; however, they are also indirectly impacted by several other documents covering the different policy fields. 
Table 1. Overview of 35 policy documents, which were analyzed for effects on soil functions. For each of the documents the general title, document type, and official number are given. For each document their impact, direct (dark gray) or indirect (light gray), on each of the five soil functions is given. If a direct impact is considered relevant, then the article numbers are given. In some cases almost the entire document has an impact on a function. In that case not all the article numbers are given, but a reference "Directive" or "Strategy" is given in the table.

\begin{tabular}{|c|c|c|c|c|c|c|c|}
\hline Agricultural Policies & Type & No. & $\begin{array}{l}\text { Production of Food, } \\
\text { Fiber and (Bio)Fuel }\end{array}$ & $\begin{array}{c}\text { Water Purification and } \\
\text { Regulation }\end{array}$ & Carbon Sequestration & $\begin{array}{c}\text { Habitat for } \\
\text { Biodiversity }\end{array}$ & $\begin{array}{c}\text { Recycling of (External) } \\
\text { Nutrients/Agro-Chemicals }\end{array}$ \\
\hline $\begin{array}{l}\text { European Agricultural Fund } \\
\text { for Rural Development }\end{array}$ & Regulation & $1305 / 2013$ & Directive & & Article 5, 34 & Article 5 & \\
\hline $\begin{array}{l}\text { Financing Management and } \\
\text { monitoring }\end{array}$ & Regulation & $1306 / 2013$ & Directive & Article 93, 94: Annex II & Article 93, 94: Annex II & Article 93, 94: Annex II & \\
\hline Direct Payment & Regulation & $1307 / 2013$ & Directive & Article 44,45 & Article 44,45 & Article 44,45 & \\
\hline $\begin{array}{l}\text { Common organization of the } \\
\text { markets }\end{array}$ & Regulation & $1308 / 2013$ & Directive & - & - & - & - \\
\hline $\begin{array}{l}\text { Plant Protection Products } \\
\text { Directive }\end{array}$ & Directive & 91/414/EEC & Article 4,b & Article 4,b & & Article 4,b & Article 4,b \\
\hline Nitrates Directive & Directive & 1991/676/EEC & Article 2 & & & & Article 2 \\
\hline GMO Directive & Directive & 2001/18/EC & Directive & Article 2-Annex II & Article 2-Annex II & Article 2-Annex II & Article 2-Annex II \\
\hline Pesticide Use Directive & Directive & 2009/128/EC & - & - & - & Article 12 & - \\
\hline \multicolumn{8}{|l|}{ Industrial policies } \\
\hline Industrial Emissions Directive & Directive & 2010/75/EU & - & & - & - & Annex II \\
\hline Landfill Directive & Directive & 1999/31/EC & - & - & - & - & - \\
\hline Mining Waste Directive & Directive & 2006/21/EC & - & - & - & - & - \\
\hline Industrial Policies & Type & No. & $\begin{array}{l}\text { Production of Food, } \\
\text { Fiber and (Bio)Fuel }\end{array}$ & $\begin{array}{c}\text { Water Purification and } \\
\text { Regulation }\end{array}$ & Carbon Sequestration & $\begin{array}{c}\text { Habitat for } \\
\text { Biodiversity }\end{array}$ & $\begin{array}{c}\text { Recycling of (External) } \\
\text { Nutrients/Agro-Chemicals }\end{array}$ \\
\hline Biocidal Products Regulation & Regulation & $528 / 2012$ & - & Article 19 & - & Article 19 & Article 19 \\
\hline Waste Directive & Directive & 2008/98/EC & ANNEX II & - & - & - & - \\
\hline \multicolumn{8}{|l|}{ Urban policies } \\
\hline Sewage Sludge Directive & Directive & 86/278/EEC & Article 6, 7 & & & & Article 8 \\
\hline Urban Waste Water Directive & Directive & 91/271/EEC & Directive & - & - & - & - \\
\hline \multicolumn{8}{|l|}{ Climate policies } \\
\hline Carbon Storage Directive & Directive & 2009/31/EC & - & - & - & - & - \\
\hline Renewable Energy Directive & Directive & 2009/28/EC & Article 17 & & & & \\
\hline $\begin{array}{l}\text { Monitoring and reporting } \\
\text { greenhouse gas emissions }\end{array}$ & Regulation & 529/2013/EU & & - & Article 7 & & - \\
\hline $\begin{array}{l}\text { Monitoring and reporting } \\
\text { greenhouse gas emissions }\end{array}$ & Communication & $\mathrm{COM} / 2016 / 479$ & - & - & - & - & - \\
\hline $\begin{array}{l}2030 \text { climate \& energy } \\
\text { framework }\end{array}$ & Communication & $\operatorname{COM}(2014) 15$ & - & - & Section 2.4 & - & - \\
\hline
\end{tabular}


Table 1. Cont.

\begin{tabular}{|c|c|c|c|c|c|c|c|}
\hline Agricultural Policies & Type & No. & $\begin{array}{l}\text { Production of Food, } \\
\text { Fiber and (Bio)Fuel }\end{array}$ & $\begin{array}{l}\text { Water Purification and } \\
\text { Regulation }\end{array}$ & Carbon Sequestration & $\begin{array}{l}\text { Habitat for } \\
\text { Biodiversity }\end{array}$ & $\begin{array}{l}\text { Recycling of (External) } \\
\text { Nutrients/Agro-Chemicals }\end{array}$ \\
\hline \multicolumn{8}{|l|}{ Nature conservation policies } \\
\hline Habitat Directive & Directive & 92/43/EEC & & - & - & & - \\
\hline Bird Directive & Directive & 2009/147/EC & & - & - & & - \\
\hline Water Framework Directive & Directive & $2000 / 60 / \mathrm{EC}$ & & Directive & - & & \\
\hline $\begin{array}{l}\text { Air quality Framework } \\
\text { Directive }\end{array}$ & Directive & 2004/107/EC & - & - & - & - & - \\
\hline $\begin{array}{l}\text { Environmental Liability } \\
\text { Directive }\end{array}$ & Directive & 2004/35/CE & - & - & - & - & - \\
\hline Nature Conservation Policies & Type & No. & $\begin{array}{l}\text { Production of Food, } \\
\text { Fiber and (Bio)Fuel }\end{array}$ & $\begin{array}{l}\text { Water Purification and } \\
\text { Regulation }\end{array}$ & Carbon Sequestration & $\begin{array}{l}\text { Habitat for } \\
\text { Biodiversity }\end{array}$ & $\begin{array}{c}\text { Recycling of (External) } \\
\text { Nutrients/Agro-Chemicals }\end{array}$ \\
\hline Floods Directive & Directive & 2007/60/EC & Article 6 & Directive & - & - & - \\
\hline $\begin{array}{l}\text { LIFE Environment } \\
\text { subprogram (2014-2020) }\end{array}$ & Regulation & No $1293 / 2013$ & Article 9: Annex III & Article 9: Annex III & Article 9: Annex III & Article 9: Annex III & Article 9: Annex III \\
\hline $\begin{array}{l}\text { LIFE Climate Action } \\
\text { subprogram (2014-2020) }\end{array}$ & Regulation & No $1293 / 2013$ & - & - & Article 14 & - & - \\
\hline Groundwater Directive & Directive & 2006/118/EC & & & - & & \\
\hline \multicolumn{8}{|l|}{$\begin{array}{l}\text { Additional environmental } \\
\text { policies }\end{array}$} \\
\hline $\begin{array}{l}\text { Environmental Impact } \\
\text { Assessment }\end{array}$ & Directive & 2011/92/EU & & & & & \\
\hline $\begin{array}{l}\text { Strategic Environmental } \\
\text { Assessment }\end{array}$ & Directive & 2001/42/EC & & & & & \\
\hline \multicolumn{8}{|l|}{$\begin{array}{l}\text { Non-binding European } \\
\text { Commission communications }\end{array}$} \\
\hline Resource Efficiency Roadmap & Communication & $\mathrm{COM} / 2011 / 571$ & Section $3.4,4.6$ & Section 4.4, 4.6 & Section 4.6 & Section 4.2, 4.6 & Section 4.6 \\
\hline $\begin{array}{l}\text { 7the Environmental Action } \\
\text { Program }\end{array}$ & Decision & $1386 / 2013$ & $\begin{array}{l}\text { Priority objective } 1: 17 \text {, } \\
28\end{array}$ & $\begin{array}{c}\text { Priority objective } 1: 23, \\
24,25,28 \\
\end{array}$ & $\begin{array}{l}\text { Priority objective 1: } 24, \\
25,28\end{array}$ & $\begin{array}{c}\text { Priority objective 1: } 24, \\
\text { 25, 28; Objective 3:54 }\end{array}$ & $\begin{array}{l}\text { Priority objective } 1: 24,25 \text {, } \\
26,28\end{array}$ \\
\hline $\begin{array}{l}\text { Forestry Sector Action Plan } \\
\text { 2014-2020 }\end{array}$ & Communication & $\operatorname{COM}(2013) / 0659$ & $\begin{array}{l}\text { Section } 3.3 .1 \text { and } \\
\text { Section 3.3.2 }\end{array}$ & Section 3.3.4 & Section 3.3.3 & & Section 3.3.4 \\
\hline Biodiversity Strategy 2020 & Communication & $\mathrm{COM} / 2011 / 244$ & Action 8,9 & Action 6,7 & Action 6,7 & Strategy 7 & \\
\hline
\end{tabular}




\subsection{National and Regional Legislation}

The impact of different national and regional legislations was evaluated towards the different soil functions. Four examples from four different countries that impact soil functions in different ways are presented as case studies.

\subsubsection{Rural Development Plan of the Emilia-Romagna Region (Italy)}

The Rural Development Plan (RDP) of the Emilia-Romagna (ER) region is one of the 118 plans foreseen within the $28 \mathrm{EU}$ Member States and one of the 22 RDPs (one national and 21 regional) in Italy [41]. The RDP's are part of the European Agricultural Fund for Rural Development (EAFRD) (EU 1305/2013) which defines how farmers can obtain additional subsidies by subscribing to different measures related to economic, environmental and social priorities. However, member states have the flexibility to decide how to use the EAFRD subsidies by setting specific objectives within their RDPs. Depending on the priorities of the country or region RDPs can differ strongly. In Emilia-Romagna the program outlines the priorities for using the nearly $€ 1.19$ billion of public money that is available for the seven-year period 2014-2020 (about $€ 513$ million from the EU budget and $€ 676$ million of national co-funding).

Emilia Romagna's RDP will fund actions under all six Rural Development priorities ("P") defined by the European Commission [42]. The measures are grouped into macro-areas, with the following budget allocation: (a) competitiveness (P2 and P3, 43\% of the budget); (b) climate and environment (P4 and P5, 43\%); (c) development of rural areas (P6, 12\%) and (d) technical assistance (2\%); (e) fostering knowledge transfer and innovation in agriculture, forestry and rural areas (P1), is distributed among the three macro-areas.

Compared to the overall European expenditure, the distribution of the money between priorities differs. For example, the budget for ecosystem restoration is lower than the European mean $(44 \%$ in Europe) and higher for resource efficiency and climate ( $8 \%$ in Europe). Of the "ecosystem restoration" (P4) budget, nearly $41 \%$ of the agricultural land will be under management contracts supporting biodiversity, $53 \%$ for water management, and $4 \%$ for soil management. Within the priority "Resource efficiency and climate" (P5) more than 50\% of the budget will be allocated for carbon storage and reduction of GHG emission, and the remaining for increasing water use efficiency and for promoting the use of renewable energy. Both "restoring, preserving and enhancing ecosystems" (P4) as well as "resource efficiency and climate" (P5) can have important direct effects on different soil functions (Scheme 1). The effects of these priorities can be evaluated by the direct impacts of specific measures on land use and land management.

The most relevant measures in relation to soil functions are aimed to: (1) increase in soil organic matter; (2) promotion of conservation agriculture; (3) promotion of organic agriculture; (4) ecosystem restoration; (5) biodiversity conservation; (6) sustainable management of extensive grasslands; (7) afforestation of agricultural lands; (8) sustainable management of animal manure. Each of these measures directly impacts one or more of the five soil functions in question. However, several other measures within the regional development plan would have relevant indirect effects on soil functions (Scheme 1). 
European Policy

Regional Policy

CAP $1305 / 2013$

$\downarrow$

European Agricultural Fund for Rural Development

Regional Rural Development Plan

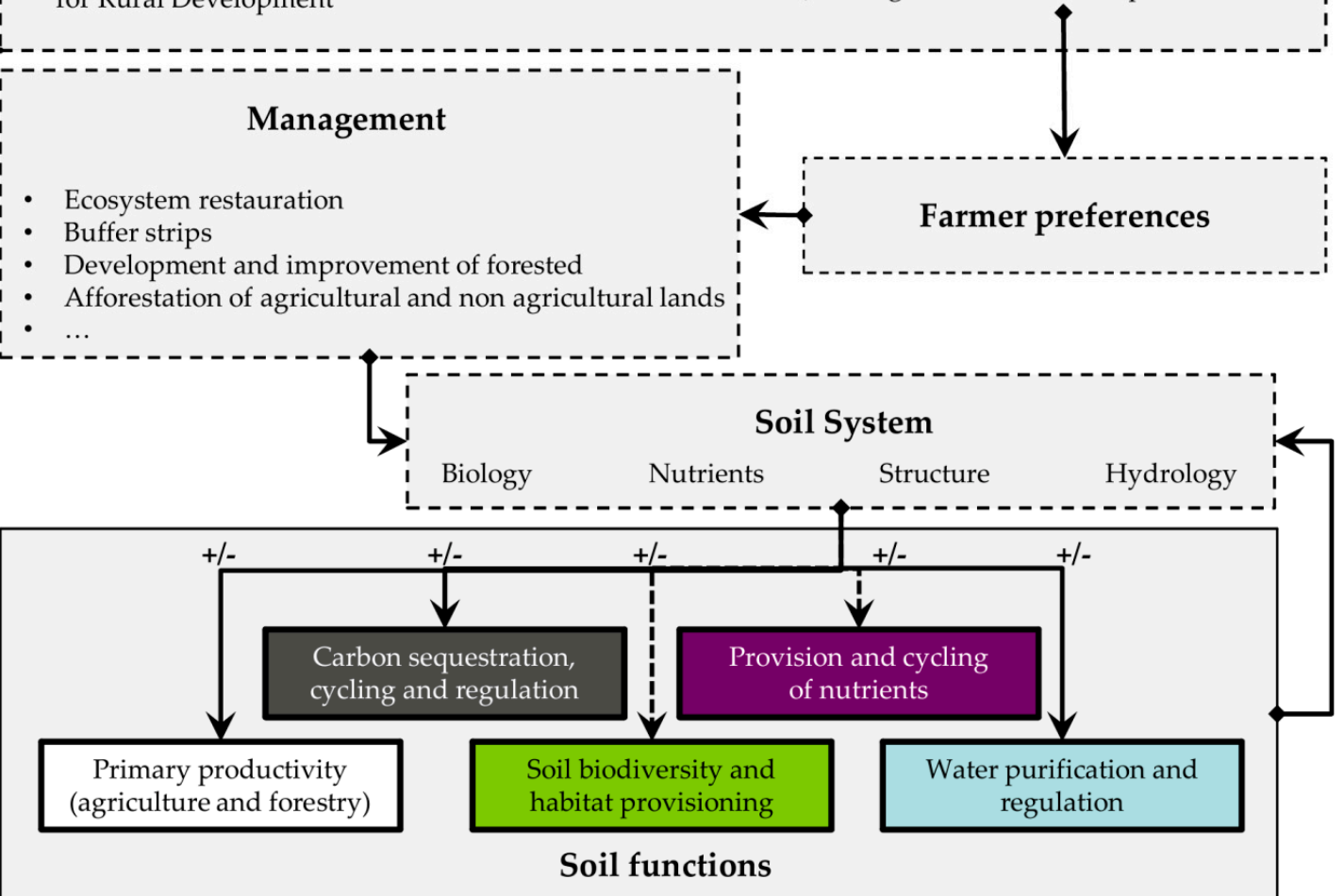

Scheme 1. Overview of the policy cascade for the Regional Rural Development Plan in Emilia-Romagna. Depending on farmer preferences, a range of management options are available that can impact the different soil functions positively and/or negatively. Dashed lines to the soil functions signify an indirect impact of the policy, while a full line signifies a direct impact. While,,+- or $+/-$ indicates an impact that is expected to be positive (+), negative (-), or either $(+/-)$, depending on the location. The colors of the soil function comply with the scheme of Schulte et al. [15].

\subsubsection{Erosion Control in Flanders (Belgium)}

In 2009 the Flemish Government initiated a regulation (B.S. 2014-02-07/28) to reduce erosion in erosion prone areas and to minimize the downstream effects of these agricultural areas. The regulation is directed towards both issues: to develop erosion prevention plans as well as stimulate local farmers to implement different types of erosion prevention measures. It integrates regional specific rules as well as EU policies directly related to the Common Agricultural Policy (CAP). Subsidies are provided to compensate farmers for their efforts toward erosion reduction. Most of the regulation activities are on a voluntary participation of both municipality and farmers, although in some cases the measures can be enforced.

The regulation in itself does not represent an implementation of EU legislation. However, part of it makes use of the cross-compliance within the direct payments regulation (EU 1307/2013) and the EAFRD (EU 1305/2013).

For farmers receiving directive payments out of the CAP, the EU imposes that they maintain a set of standards on Good Agricultural and Environmental Conditions (GAEC) of the soil. If standards are not reached or maintained, direct payments to the farmers can be reduced. Some of these conditions are related to a specific set of practices that also encompasses some erosion related practices such as: 
- Soil erosion prevention: provide minimum soil cover (GAEC 4).

- Maintain of soil organic matter and soil structure (GAEC 6).

- Retention of landscape features including ban on cutting hedges and trees during the bird breeding and rearing season (GAEC 7).

Cross-compliance is only implemented in some areas and only for a limited period of time. It is used to force farmers in the most erosion vulnerable areas to take action and implement the required management practices. These practices are mandatory for these farmers and no compensations are provided in these cases. Instead, reductions in direct payments can be used as fines. In the other areas that are less erosion vulnerable, only voluntary participation of the farmers is encouraged through subsidies. Funds for these subsidies come from the EAFRD through the Flemish RDP.

The policy addresses primary productivity as a function directly (Scheme 2). The goal is to keep fertile soil in the fields and maintain soil fertility over a long period of time to ensure high primary productivity in the future. However, the other functions, particularly carbon storage, are all indirectly impacted through this policy. Although carbon sequestration is not the final goal of the regulation, it is an important factor that is taken into account when evaluating the implementation of cross-compliance. When the organic carbon content reaches specific levels, agricultural land can be reevaluated to less erosion prone areas and fields can change from mandatory management to voluntary management. This allows the farmer to apply for subsidies for additional erosion control measures.

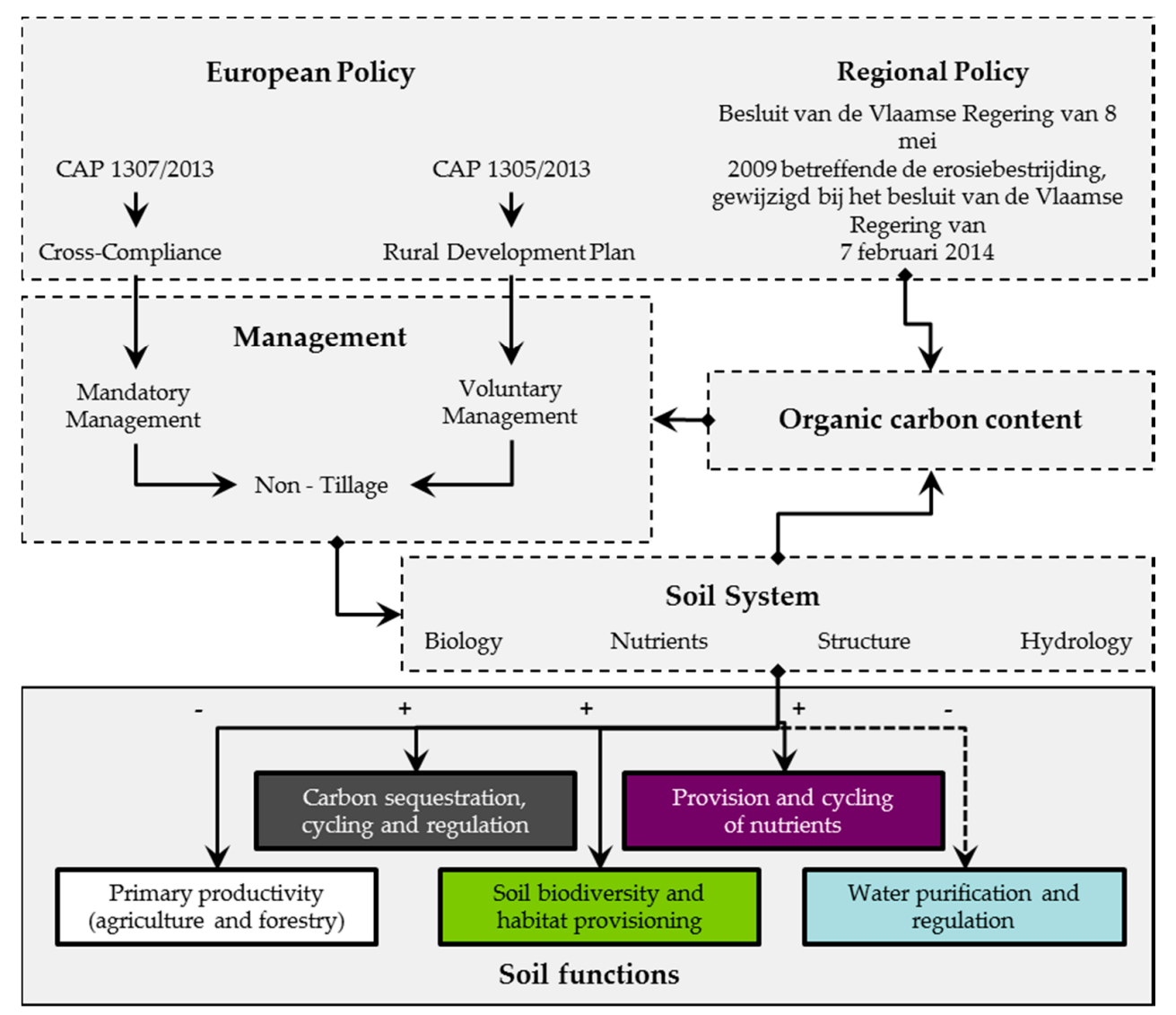

Scheme 2. Overview of the policy cascade for the erosion control regulation in Flanders. An interaction between direct payments and the Flemish rural development program encourage farmers to increase their organic carbon content in the soil. Dashed lines to the soil functions signify an indirect impact of the policy, while a full line signifies a direct impact. While,,+- or $+/-$ indicates an impact that is expected to be positive $(+)$, negative $(-)$, or either $(+/-)$, depending on the location. The colors of the soil function comply with the scheme of Schulte et al. [15]. 
The other functions considered are also affected to some degree by the erosion measures. For example the provision of functional and intrinsic biodiversity is positively affected through measures such as grass buffers and small landscape elements in and around the fields as they can significantly increase soil biodiversity [43]. The provision and cycling of nutrients are affected through measures such as non-tillage that can improve the nutrient provisioning and cycling within the field [44], while water purification and regulation are improved through the reduction in erosion [45]. Several of the measures are developed to reduce and slow down surface runoff and to increase infiltration.

\subsubsection{Soil Quality and Contaminated Site Management in The Netherlands}

While soil contamination is one of the eight threats highlighted in the EU Thematic Soil Strategy, management of soil contamination currently takes place on a national or regional level. The policy framework of contaminated site management in The Netherlands, established in 1986, was initially designed to remove the risks of all contaminated sites present in the country [46]. Article 1 states that "soils need protection because of the functional role of soil for humans, plants and animals". Furthermore, "soil is the upper layer of earth's crust with liquid, gaseous and solid components including organisms". Until 1998, seriously contaminated sites had to be remediated to the multifunctional state, that is, clean enough to allow all possible land uses with no risks for any endpoint. After 1998, the 'multifunctional' approach was withdrawn, and a fit-for-use approach was adopted allowing remediation objectives that took account of the eventual land use. For example, nature areas have stricter remediation objectives (maximal values) than industrial areas. In summary, the soil contamination policy evaluates potentially contaminated sites based on Background (low), Maximal (medium: value is set per land use category), and Intervention (high) values [46]. When concentrations of contaminants are between the Background and Maximal value, certain use limitations are set (urban use, industry, etc.). When values are above the Intervention value a risk assessment has to be performed (Circular on soil remediation) and specific mitigating actions have to be taken. The risk assessment system makes use of a stepwise approach: each step adds site-specific information to the evaluation. In Step 2 of the ecological risk assessment, the functioning of the ecosystem is evaluated through application of Species Sensitivity Distributions [47]. In the third step of the risk assessment a Soil Quality Triad is used, taking ecological, soil chemical and eco-toxicological data from the site into account (Scheme 3). In this way, the functioning of the soil ecosystem is evaluated by focusing on the species and processes at the site, following the principle that all species are different, but equally important for the functioning of the ecosystem [47].

In 2003, the Dutch government announced a change of the soil policy in many aspects. Firstly, not only was contamination considered a threat to the functioning of the soils, but also other types of pressures, such as erosion, sealing and biodiversity decrease. In addition, for the first time the use approach was declared to be a step forward following acceptance and adoption of the concept of ecosystem services and natural capital $[48,49]$. Soil could, and should, be managed (modified) to deliver requested ecosystem services; however, rules for sustainable management still need to be adopted (Scheme 4). This approach created further innovations in soil policy and management, providing an alternative from strict protection of soils to a land use and management approach, with an optimization of a bundle of ecosystem services through stakeholder participation. The use approach is elaborated in the second soil covenant (agreement between parties about remediation and sustainable soil management (Covenant soil and subsoil, 17 March 2015, The Hague, The Netherlands) and will be further elaborated in the new overarching Environment Act after 2019. 


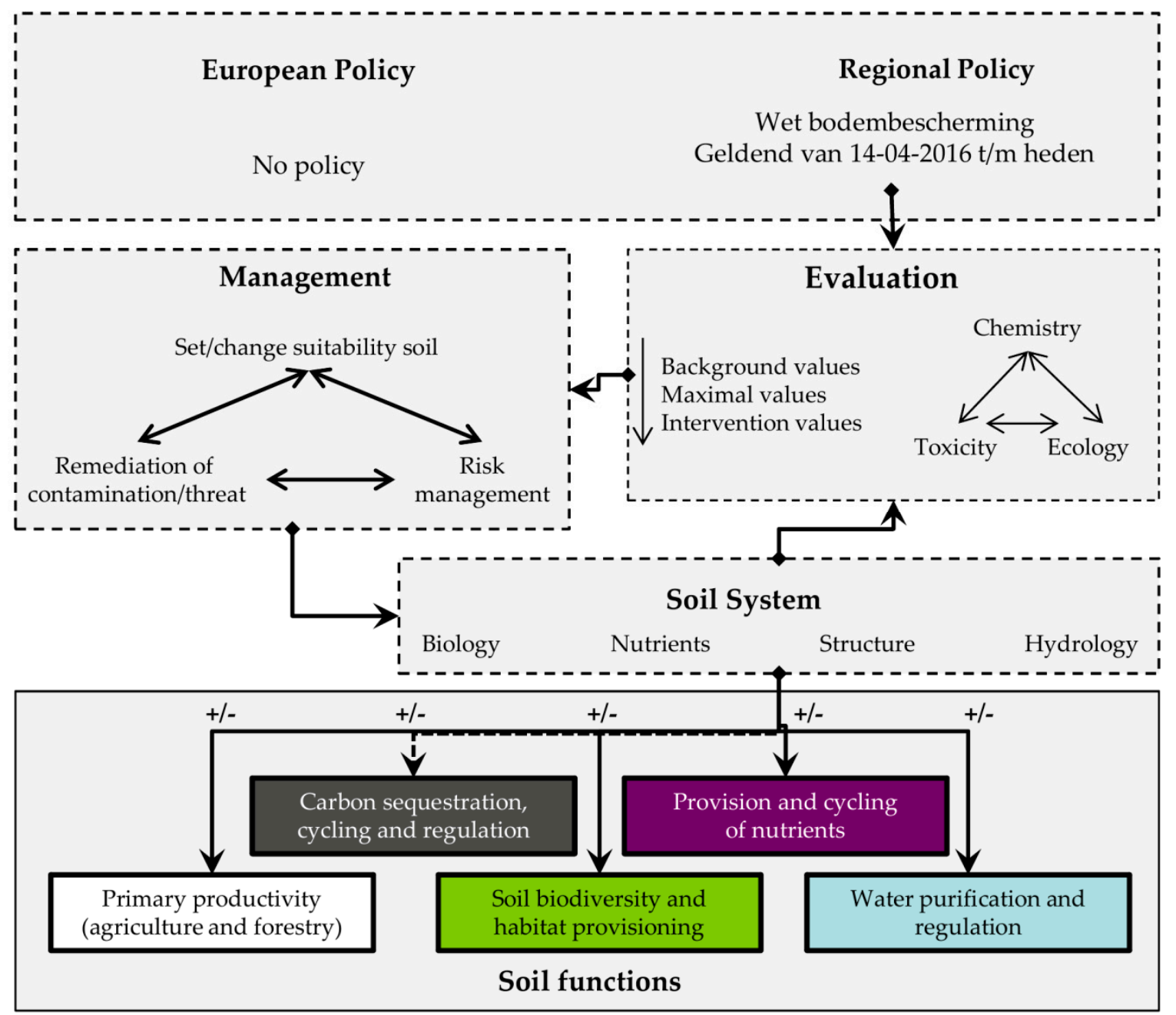

Scheme 3. Overview of the policy cascade for the soil protection law in The Netherlands. An evaluation system allows for targeted management schemes, ensuring soil health and effecting the different soil functions as much as possible in a positive way. Dashed lines to the soil functions signify an indirect impact of the policy, while a full line signifies a direct impact. While,,+- or $+/-$ indicates an impact that is expected to be positive (+), negative $(-)$, or either $(+/-)$, depending on the location. The colors of the soil function comply with the scheme of Schulte et al. [15].

\subsubsection{Upper-Austrian Regional Spatial Development Program (Austria)}

Soil protection in Austria is integrated in the constitution; however, the federal states have delegated responsibilities. As a result, policies can differ significantly between regions and only some regions have implemented significant soil-related policies and evaluation systems. The regional government authority of Upper Austria uses a model that tries to achieve comparability of different public interests on a regional scale by integrating different landscape related issues such as "spatial resistance of water" and "settlement and transport development" in one Regional Spatial Development Concept [50]. The regional government only recently integrated soil resistance in this overarching evaluation system. According to the regional soil conservation act, soil functions are evaluated according to six units: "habitat for soil organisms", "potential as a habitat for natural plant communities", "natural soil fertility", "infiltration and drainage regulation", "filter and buffer for pollutants" and "archive of natural and cultural history". The evaluation system assesses each soil type available within the region on its functional performance for each function and its spatial resistance. Spatial resistance is designated as the conflict potential with building development and 
related purposes. By combining these different elements into one value the "total spatial resistance of soil" is calculated.

By combining the spatial resistance of the soil with other elements, such as "spatial resistance of water", a spatial vision of the landscape can be developed and integrated in the Regional Spatial Development Concept. By making the results of this evaluation publicly available, Upper-Austrian municipalities are gradually incorporating this into their communal spatial programs. As a result, Upper-Austria should ensure the long-term delivery of the different soil functions and minimize the impact of further spatial developments in the future (Scheme 4).

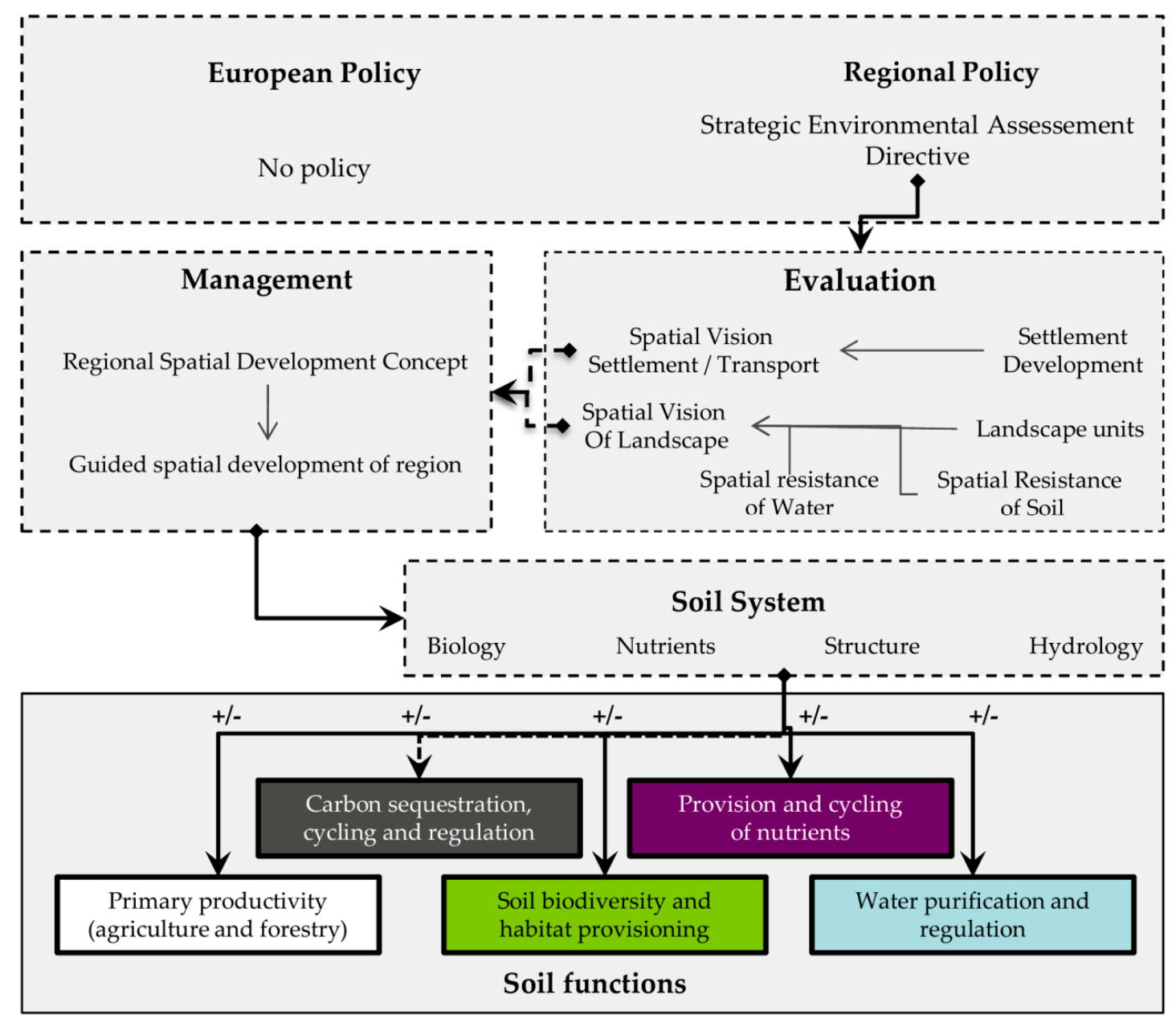

Scheme 4. Overview of the policy cascade for the Regional Spatial Development Program in Upper Austria. A spatial evaluation system allows for the development of regional and local spatial development concepts. These concepts should guide spatial development in the region ensuring the sustainable delivery of the different soil functions. Dashed lines to the soil functions signify an indirect impact of the policy, while a full line signifies a direct impact. While,,+- or $+/-$ indicates an impact that is expected to be positive $(+)$, negative $(-)$, or either $(+/-)$, depending on the location. The colors of the soil function comply with the scheme of Schulte et al. [15].

\section{Discussion}

This paper has clearly shown that some EU policies influence all five soil functions both directly and indirectly. When evaluating the Directives and Regulations individually, the general impact on a function can usually be determined. Since most Directives and many Regulations are legislative documents that need to be applicable throughout the wide range of climates, soils, ecosystems and agricultural practices in the EU, most policy documents remain open and many of the policies that 
have an effect on soil functions are only further specified on a national or regional scale. As a result, the direction (positive or negative effect) and magnitude of effect on a specific function can differ between regions and locations and cannot be assessed through an evaluation of the EU policy documents alone.

The drafting of a specific EU policy is hardly ever the endpoint of the political process. How EU policy documents are implemented and integrated within national and regional legislation has a distinct impact on the eventual outcome. Even for Regulations, which are more specific than Directives, such as the CAP, individual countries and regions still have much flexibility how to implement them. Especially through the EAFRD, regions have a wide range of management options to choose from that can have an effect on soil functions. As a result, it can be expected that RDPs have significant effects on soil functions, depending on the interests of the region in question. How much of the EAFRD is spent on the designated priorities that are related to soil functions and which measures exactly are funded is decided by the national and/or regional authorities. The example for Emilia-Romagna illustrates how regional RDPs can differ from the European averages. Whether or not, and how and where, management actions are taken are decisions largely defined by regions and farmers. As a result, understanding the overall impact of a specific policy on the different soil functions on a local scale remains a challenge.

The withdrawal of the proposal for a Soil Framework Directive demonstrates that, for a variety of reasons, some member states are reluctant to push for a broad EU policy approach to management of soil threats. In the meantime, soil is being offered some degree of protection through indirect consequences of other EU legislation (e.g., industrial emissions, water framework, GAEC measures in the CAP). However, many of these do not specify soil-based targets or thresholds. Some countries, such as Germany and Austria, already have extended soil protection laws and have the concept of soil functions already integrated in their legislation. However, this is not the case for many other countries where legislation that affects soil functions is fragmented between different policies or sometimes even disregarded. Because of the interactions that can occur between levels of legislation, legislative domains, and soil properties, processes, and functions it is difficult to investigate in which areas the functions are well protected, managed, or even promoted. In many policy fields, all legislative power still resides with the regional and national government. Examples such as contaminated site management illustrate how local policy levels can impact soils and even integrate soil functions in their policies. However, this fragmentation makes it difficult to understand at which policy level the most important driving policies are implemented. The interactions between the different policy levels should be investigated firstly in order to understand how soil functions are impacted.

Soil biodiversity, which is imperative for the performance of the other functions, is known to recover slowly from disturbance [51]. Short-term measures that can be moved each year throughout the agricultural landscape such as fallow land and buffer strips mostly have only limited or temporary effects on the soil functions considered. New disturbances after the short-term measures can deteriorate biodiversity again. When there is a requirement to move to a more sustainable management of soils, potential measures and policies should be evaluated on their long-term, lasting effects and be implemented at the relevant scale. Nature conservation policies are generally more stable since the areas to which they apply are designated over longer or even indefinite periods. NATURA 2000 legislation, for example, has no end date, while the CAP is revised every six years. However, nature conservation policies only apply to specific areas within the European territory. For example, the Birds Directive (2009/147/EC) has only an impact within areas that are designated as Special Protection Areas and are part of the Natura 2000 network. Therefore, all management actions taken on agricultural parcels within Natura 2000 sites (through cross-compliance), although they will provide long-term stability, will only affect a limited part of the total agricultural areas. Besides these stable interventions, regulations and communications that are applicable for only limited periods, such as the CAP and the Climate Framework, can also be adapted more easily to recent scientific knowledge and trends. Finding a balance between the long-term maintenance and development of the different soil functions 
and providing options for adaptation to changes in farming and the environment will be a challenge for the upcoming years.

EU policies can be considered as a baseline for the impact on soil functions. Often member states decide to use specific EU policies as a stepping stone to more extended laws. In the case study of Flanders, parts of the CAP were integrated in an overall policy for erosion prevention. Therefore, EU policies often have an indirect impact by initiating more extended regional and national laws, thus increasing its relevance and importance.

Of all the policy documents reviewed, none of them directly deals with the maintenance of the bundle of all soil functions. In most cases, only a few functions are affected directly or indirectly within specific designated areas. Soils have specific properties which make one type better in providing a soil function compared to another [52]. Current policy and management actions are put in place to reach other objectives that are not related to soil functions and they do not access soils in their capacity to provide soil functions. At the same time resilience of soil functions on the long-term is not addressed either.

The Soil Thematic Strategy was intensively discussed after the abandoning of the directive, as other upcoming legislation could have important impacts on soil functions. In particular, the Regulations that implement the Climate and Energy Framework 2030 into EU legislation can have an impact on several soil functions beyond carbon sequestration. Under the proposal, greenhouse gas emissions from land use, land use change and forestry (LULUCF) will become part of the non-ETS (Emissions Trading System) impacting land management on a broad scale (COM/2016/0479). As a result, countries will have to report on their greenhouse gas emissions that are caused by changes in land cover, land use, and forestry in a systematic manner and, in time, total emissions will have to be reduced to zero. In the end, governments will have to assess carbon storage management in the soils, providing opportunities to improve the soil function "Carbon sequestration" and others.

In order to come to a cohesive integration of soil functions in EU, national and regional policies harmonized targets and monitoring and evaluation methods should be developed that are applicable across the EU Member States. The measurement and assessment of soil functions is accompanied by uncertainties. Therefore robust and reliable proxies have to be developed that are able to detect changes in the availability of these functions under different conditions (e.g., different land use categories, climate zones, etc.). As a result, the actual implementation of soil functions in policy and management faces not only political but also practical challenges that need to be resolved.

\section{Conclusions}

In the EU, soil functions are impacted by different policy domains and levels of legislation. As a result, there is a large spatial difference in the impacts on the different soil functions. Some functions are directly addressed by a policy, whereas others may be indirectly addressed, depending on the policy and on the location or region where it applies. Since the functional management of soils remains an issue within the EU, new approaches for an integrated assessment of soil functions offer opportunities to support environmental policy in agricultural landscapes much more efficiently. However, more research is needed on the combined effect of European and regional policies on soil functions in agricultural ecosystems to understand their full combined effects.

Acknowledgments: This study was conducted as part of the LANDMARK (LAND Management: Assessment, Research, Knowledge Base) project. LANDMARK has received funding from the European Union's Horizon 2020 research and innovation program under grant agreement No. 635201.

Author Contributions: Dirk Vrebos, Ciro Gardi, Arwyn Jones, Michiel Rutgers, and Jan Staes conceived the analysis and outline of the paper. Dirk Vrebos performed the analysis of the European policy documents in collaboration with Arwyn Jones and Francesca Bampa. Different authors attributed with their local expertise and provided the regional examples: Italy-Ciro Gardi; Flanders-Patrick Meire and Jan Staes, The Netherlands-Michiel Rutgers, and Austria-Taru Sandén. Dirk Vrebos, Ciro Gardi, Arwyn Jones, Michiel Rutgers, and Francesca Bampa wrote the paper in close collaboration with the other authors regarding the 
regional examples. Rachel E. Creamer and Bhim Bahadur Ghaley provided relevant comments and information regarding introduction and discussion. Overall coordination of the research and writing was done by Dirk Vrebos.

Conflicts of Interest: The author Ciro Gardi is employed with the European Food Safety Authority (EFSA) in its Alpha Unit, which provides scientific and administrative support to the Plant Health Panel and EFSA's scientific activities in the same area. However, the present article is published under the sole responsibility of the author and may not be considered an EFSA scientific output. The positions and opinions presented in this article are those of the author alone and are not intended to represent the views or scientific works of EFSA. To know about the views or scientific outputs of EFSA, please consult its website under http:/ / www.efsa.europa.eu. Arwyn Jones is employed by the European Commission DG JRC and the views expressed are purely those of the writer and may not in any circumstances be regarded as stating an official position of the European Commission.

\section{References}

1. Power, A.G. Ecosystem services and agriculture: Trade-offs and synergies. Philos. Trans. R. Soc. B Biol. Sci. 2010, 365, 2959-2971. [CrossRef] [PubMed]

2. Huang, J.; Tichit, M.; Poulot, M.; Darly, S.; Li, S.C.; Petit, C.; Aubry, C. Comparative review of multifunctionality and ecosystem services in sustainable agriculture. J. Environ. Manag. 2015, 149, $138-147$. [CrossRef] [PubMed]

3. Swinton, S.M.; Lupi, F.; Robertson, G.P.; Hamilton, S.K. Ecosystem services and agriculture: Cultivating agricultural ecosystems for diverse benefits. Ecol. Econ. 2007, 64, 245-252. [CrossRef]

4. Dale, V.H.; Polasky, S. Measures of the effects of agricultural practices on ecosystem services. Ecol. Econ. 2007, 64, 286-296. [CrossRef]

5. Alexandratos, N.; Bruinsma, J. World Agriculture towards 2030/2050: The 2012 Revision; FAO: Rome, Italy, 2012.

6. Tilman, D.; Balzer, C.; Hill, J.; Befort, B.L. Global food demand and the sustainable intensification of agriculture. Proc. Natl. Acad. Sci. USA 2011, 108, 20260-20264. [CrossRef] [PubMed]

7. Squire, G.R.; Hawes, C.; Valentine, T.A.; Young, M.W. Degradation rate of soil function varies with trajectory of agricultural intensification. Agric. Ecosyst. Environ. 2015, 202, 160-167. [CrossRef]

8. Gomiero, T. Soil degradation, land scarcity and food security: Reviewing a complex challenge. Sustainability 2016, 8, 281. [CrossRef]

9. Bouma, J. Soil science contributions towards sustainable development goals and their implementation: Linking soil functions with ecosystem services. J. Plant Nutr. Soil Sci. 2014, 177, 111-120. [CrossRef]

10. Adhikari, K.; Hartemink, A.E. Linking soils to ecosystem services-A global review. Geoderma 2016, 262, 101-111. [CrossRef]

11. Blum, W.E.H. Functions of soil for society and the environment. Rev. Environ. Sci. Bio/Technol. 2005, 4, 75-79. [CrossRef]

12. Tóth, G.; Stolbovoy, V.A.; Montanarella, L. Soil Quality and Sustainability Evaluation-An Integrated Approach to Support Soil-related Policies of the European Union; European Commission: Luxembourg, 2007; p. 40.

13. Dominati, E.; Patterson, M.; Mackay, A. A framework for classifying and quantifying the natural capital and ecosystem services of soils. Ecol. Econ. 2010, 69, 1858-1868. [CrossRef]

14. Lehmann, A.; Stahr, K. The potential of soil functions and planner-oriented soil evaluation to achieve sustainable land use. J. Soils Sediments 2010, 10, 1092-1102. [CrossRef]

15. Schulte, R.P.O.; Bampa, F.; Bardy, M.; Coyle, C.; Fealy, R.; Gardi, C.; Ghaley, B.; Jordan, P.; Laudon, H.; O'Dononghue, C.; et al. Making the most of our land: Managing soil functions from local to continental scale. Front. Environ. Sci. 2015, 3, 81. [CrossRef]

16. Palm, C.; Sanchez, P.; Ahamed, S.; Awiti, A. Soils: A contemporary perspective. In Annual Review of Environment and Resources; Annual Reviews: Palo Alto, CA, USA, 2007; Volume 32, pp. 99-129.

17. McKenzie, F.C.; Williams, J. Sustainable food production: Constraints, challenges and choices by 2050. Food Secur. 2015, 7, 221-233. [CrossRef]

18. UN (United Nations). 68/232 World Soil Day and International Year of Soils; United Nations General Assembly, Ed.; UNGAOR: Washington, DC, USA, 2014.

19. Keesstra, S.D.; Bouma, J.; Wallinga, J.; Tittonell, P.; Smith, P.; Cerdà, A.; Montanarella, L.; Quinton, J.N.; Pachepsky, Y.; van der Putten, W.H.; et al. The significance of soils and soil science towards realization of the United Nations sustainable development goals. Soil 2016, 2, 111-128. [CrossRef]

20. FAO; ITPS. Status of the World's Soil Resources (swsr)—Main Report; Food and Agriculture Organization of the United Nations; Intergovernmental Technical Panel on Soils: Rome, Italy, 2015. 
21. Blum, W.E.H.; Büsing, J.; Montanarella, L. Research needs in support of the European thematic strategy for soil protection. TrAC Trend. Anal. Chem. 2004, 23, 680-685. [CrossRef]

22. European Commission (EC). Communication from the Commission to the Council, the European Parliament, the European Economic and Social Committee and Committee of the Regions "Towards a Thematic Strategy for Soil Protection" (com(2002)179). 2002. Available online: http://eur-lex.europa.eu/legal-content/CS/ ALL/?uri=URISERV:128122 (accessed on 1 March 2017).

23. European Commission (EC). Proposal for a Directive of the European Parliament and of the Council Establishing a Framework for the Protection of Soil and Amending Directive 2004/35/ec (com(2006)232). 2006. Available online: http:/ / eur-lex.europa.eu/legal-content/EN/TXT/?uri=CELEX\%3A52006PC0232 (accessed on 7 March 2017).

24. Glaesner, N.; Helming, K.; de Vries, W. Do current European policies prevent soil threats and support soil functions? Sustainability 2014, 6, 9538-9563. [CrossRef]

25. Louwagie, G.; Gay, S.H.; Sammeth, F.; Ratinger, T. The potential of European Union policies to address soil degradation in agriculture. Land. Degrad. Dev. 2011, 22, 5-17. [CrossRef]

26. European Commission (EC). Withdrawal of Obsolete Commission Proposals 2014/c 153/03. 2014. Available online: http:/ / eur-lex.europa.eu/legal-content/EN/TXT/?uri=uriserv\%3AOJ.C_.2014.153.01.0003.01.ENG (accessed on 1 March 2017).

27. Daniel, F.J. Variations in rural development: A comparative analysis of the application of the rural development regulation framework in France and The Netherlands. NJAS Wageningen J. Life Sci. 2008, 56, 7-19. [CrossRef]

28. Virto, I.; Imaz, M.J.; Fernandez-Ugalde, O.; Gartzia-Bengoetxea, N.; Enrique, A.; Bescansa, P. Soil degradation and soil quality in Western Europe: Current situation and future perspectives. Sustainability 2015, 7, 313-365. [CrossRef]

29. Günal, H.; Korucu, T.; Birkas, M.; Özgöz, E.; Halbac-Cotoara-Zamfir, R. Threats to sustainability of soil functions in Central and Southeast Europe. Sustainability 2015, 7, 2161-2188. [CrossRef]

30. Rodrigues, S.M.; Pereira, M.E.; da Silva, E.F.; Hursthouse, A.S.; Duarte, A.C. A review of regulatory decisions for environmental protection: Part $\mathrm{i}$-challenges in the implementation of national soil policies. Environ. Int. 2009, 35, 202-213. [CrossRef] [PubMed]

31. Italian Government. Decreto Legislativo 3 Aprile 2006, n. 152, norme in Materia Ambientale; Italian Government, Ed.; Gazzetta Ufficiale: Rome, Italy, 2016; Volume 96. Available online: http://www.gazzettaufficiale. it/atto/serie_generale/caricaDettaglioAtto/originario?atto.dataPubblicazioneGazzetta=2006-04-14\&atto. codiceRedazionale=006G0171 (accessed on 1 March 2017). (In Italian)

32. BGBl-Bundesgesetzblatt. Besetz Zum Schutz vor Schädlichen Bodenveränderungen und zur Sanierung von Altlasten (Bundes-bodenschutzgesetz—bbodschg); Bundesministeriums der Justiz: Berlin, Germany, 1998; Available online: https:/ /www.gesetze-im-internet.de/bundesrecht/bbodschg/gesamt.pdf (accessed on 1 March 2017). (In Italian)

33. Kibblewhite, M.G.; Miko, L.; Montanarella, L. Legal frameworks for soil protection: Current development and technical information requirements. Curr. Opin. Environ. Sustain. 2012, 4, 573-577. [CrossRef]

34. Haygarth, P.M.; Ritz, K. The future of soils and land use in the uk: Soil systems for the provision of land-based ecosystem services. Land Use Policy 2009, 26, S187-S197. [CrossRef]

35. Schulte, R.P.O.; Donnellan, T.; O’hUallachain, D.; Creamer, R.; Fealy, R.; Farrelly, N.; O’Donoghue, C. Functional soil planning: Can policies address global challenges with local action? In Proceedings of the Wageningen Conference on Applied Soil Science-Soil Science in a Changing World, Wageningen, The Netherlands, 18-22 September 2011; p. 139.

36. Bouma, J.; Broll, G.; Crane, T.A.; Dewitte, O.; Gardi, C.; Schulte, R.P.O.; Towers, W. Soil information in support of policy making and awareness raising. Curr. Opin. Environ. Sustain. 2012, 4, 552-558. [CrossRef]

37. Schulte, R.P.O.; Creamer, R.E.; Donnellan, T.; Farrelly, N.; Fealy, R.; O’Donoghue, C.; O’hUallachain, D. Functional land management: A framework for managing soil-based ecosystem services for the sustainable intensification of agriculture. Environ. Sci. Policy 2014, 38, 45-58. [CrossRef]

38. Coyle, C.; Creamer, R.E.; Schulte, R.P.O.; O'Sullivan, L.; Jordan, P. A functional land management conceptual framework under soil drainage and land use scenarios. Environ. Sci. Policy 2016, 56, 39-48. [CrossRef] 
39. Kutter, T.; Louwagie, G.; Schuler, J.; Zander, P.; Helming, K.; Hecker, J.M. Policy measures of agricultural soil conservation in the European Union and its member states: Policy review and classification. Land. Degrad. Dev. 2011, 22, 18-31. [CrossRef]

40. European Commision (EC). Directive 2009/31/ec of the European Parliament and the Council of 23 april 2009 on the Geological Storage of Carbon Dioxide and Amending Council Directive 85/337/eec, European Parliament and cOuncil Directives 2000/60/ec, 2001/80/ec, 2004/35/ec, 2006/12/ec, 2008/1/ec and Regulation (ec) No 1013/2006; European Commision, Ed.; European Commision: Brussels, Belgium, 2009; Available online: http:/ /eur-lex. europa.eu/legal-content/EN/TXT/?uri=celex:32009L0031 (accessed on 1 March 2017). (In Italian)

41. Leardini, A.C.; Serventi, S. The cultural landscape of food: The infrastructure resilience of via emilia. In Sustainable Urban Agriculture and Food Planning; Roggema, R., Ed.; Routledge: Oxford, UK, 2016; p. 286.

42. European Commission (EC). Factsheet on 2014-2020 Rural Development Programme for Emilia-Romagna; European Commission: Brussels, Belgium, 2017.

43. Lovell, S.T.; Sullivan, W.C. Environmental benefits of conservation buffers in the United States: Evidence, promise, and open questions. Agric. Ecosyst. Environ. 2006, 112, 249-260. [CrossRef]

44. Van Oost, K.; Govers, G.; de Alba, S.; Quine, T.A. Tillage erosion: A review of controlling factors and implications for soil quality. Prog. Phys. Geogr. 2006, 30, 443-466. [CrossRef]

45. Lenat, D.R. Agriculture and stream water quality-A biological evaluation of erosion control practices. Environ. Manag. 1984, 8, 333-343. [CrossRef]

46. Swartjes, F.A.; Rutgers, M.; Lijzen, J.P.A.; Janssen, P.J.C.M.; Otte, P.F.; Wintersen, A.; Brand, E.; Posthuma, L. State of the art of contaminated site management in The Netherlands: Policy framework and risk assessment tools. Sci. Total Environ. 2012, 427-428, 1-10.

47. Posthuma, L.; Suter, G.W.; Traas, T.P. Species Sensitivity Distributions in Ecotoxicology; CRC Press: Boca Raton, FL, USA, 2001.

48. Costanza, R.; d'Arge, R.; deGroot, R.; Farber, S.; Grasso, M.; Hannon, B.; Limburg, K.; Naeem, S.; Oneill, R.V.; Paruelo, J.; et al. The value of the world's ecosystem services and natural capital. Nature 1997, 387, $253-260$. [CrossRef]

49. MEA. Millennium Ecosystem Assessment: Ecosystems and Human Well-Being: Synthesis; Island Press: Washington, DC, USA, 2005.

50. Haslmayr, H.P.; Geitner, C.; Sutor, G.; Knoll, A.; Baumgarten, A. Soil function evaluation in Austria-development, concepts and examples. Geoderma 2016, 264, 379-387. [CrossRef]

51. Adl, S.M.; Coleman, D.C.; Read, F. Slow recovery of soil biodiversity in sandy loam soils of Georgia after 25 years of no-tillage management. Agric. Ecosyst. Environ. 2006, 114, 323-334. [CrossRef]

52. Nortcliff, S. Standardisation of soil quality attributes. Agric. Ecosyst. Environ. 2002, 88, 161-168. [CrossRef]

(C) 2017 by the authors. Licensee MDPI, Basel, Switzerland. This article is an open access article distributed under the terms and conditions of the Creative Commons Attribution (CC BY) license (http:/ / creativecommons.org/licenses/by/4.0/). 